https://doi.org/10.36059/978-966-397-176-6/1-20

\title{
MAIN TRENDS OF FORMATION OF READING CULTURE BY MEANS OF THE INTERNET
}

\section{Bessarab A. O.}

\section{INTRODUCTION}

According to study results by Factum Group Ukraine company, the total Internet audience across Ukraine, excluding Crimea, has increased to $59 \%$ and is 21,8 million of users ${ }^{1}$. According to estimates by InMind company at the request of Ukrainian Internet Association, by first quarter of 2015 in Ukraine, there were about 25 million real Internet users (i.e. those who use the Net once a month and more often). As L. Yevdochenko, the Head of the State Service of Special Communication and Information Protection of Ukraine, reported at the Parliament hearings on reformation of information and communication technologies field and development of Ukraine information space, in 2015 more than $58 \%$ of Ukraine citizens regularly use the Internet ${ }^{2}$. As RBK-Ukraine reports with reference to data from the State Statistics Service of Ukraine, «by 1 April 2019, the number of Internet subscribers in Ukraine was 26,38 million people, which is by $1,2 \%$ (by 313 thousand) more, than at the beginning of the year. According to the statistic institution, the number of Internet subscribers - natural persons increased by $1,1 \%$ (by 245 thousand) to 23,6 million people» ${ }^{3}$.

Therefore, activities aimed to formation of interest in reading of Ukrainian books with the help of the Internet have great potential.

\footnotetext{
${ }^{1}$ Кількість регулярних інтернет-користувачів в Україні зросла до 21,8 млн. gazeta.ua. URL: http://gazeta.ua/articles/life/_kilkist-regulyarnih-internetkoristuvachiv-v-ukrayini-zroslado-218-mln/633061 (дата звернення: 22.06.2019).

${ }^{2}$ У 2015 році регулярно Інтернетом користувалося понад 58\% жителів України. URL: http://www.unian.ua/society/1254409-u-2015-rotsi-kilkist-internet-koristuvachiv-v-ukrajinistanovilo-ponad-58.html (дата звернення: 22.06.2019).

${ }^{3}$ Кількість інтернет-користувачів в Україні продовжує зростати. РБК-Украӥна: сайт. URL: https://www.rbc.ua/ukr/news/kolichestvo-internet-polzovateley-ukraine-1558443228.html (дата звернення: 22.06.2019).
} 


\section{The pedagogical potential of the Internet in the formation of reading culture}

As M. Lukina rightly notes, «the aspect of communication interactivity is considered as one of the Internet media features (the first two are hipertextuality and multimediality. $-A$. B.), and the Internet itself - as a unique channel to establish connections with end users, allowing a quick response not only for certain individuals, but also for quite big amount of people. In practice, the editors of Internet media use various established formats of the network communication: emails, forums, ratings, votes, etc. No doubt, this widens the range of media communicative possibilities - from monologue and dialogue of the editors with certain representatives of the audience to a forum, when the discussion of agenda takes place in multilateral mode between all participants of the communication process» ${ }^{4}$.

As for Ukrainian media, it is quite possible to cite the features of Russian media in the Internet, outlined by M. Lukina: «they have their own social niche, which is significantly different from the audience of "old" media (not as numerous, but younger, richer and more educated); they have new opportunities in speed and promptness in the updating of their information; they are more flexible in approaches to fixed frequency; they have cross-border area of spreading, with that they are local by possibility of access to small social groups, dispersed by interests and territories; they differ in areas of information focus that possess both universalism and borderline specialization, which serves to interests of certain segments of an audience; they possess hypertextuality, which gives unique opportunities for both producers and consumers of media product; they are multimedia by their essence, i.e. they have a possibility to send messages in various sign systems - verbal, graphic, sound, photo, video, animation; they are unique in terms of

${ }^{4}$ Лукина М. М. СМИ в Интернете. Средства массовой информации России: учеб. пособ. для студентов вузов / М. И. Алексеева, Л. Д. Болотова, Е. Л. Вартанова и др.; под ред. Я. Н. Засурского. Москва: Аспект-Пресс, 2006. С. 345. 
interactivity, i.e. multilateral information exchange with consumers both with certain representative and audience as a whole» ${ }^{5}$.

Books move away from the massive segment of engagement - TV and radio advertisement, as well as contextual advertisement - to the segment of engagement by recommendations. More and more people are buying books by recommendation of family and friends, of authoritative people.

In current situation, almost every active publishing company has to have the own website and pages in social networks and use blogging means actively. An effective way is to use the possibility to turn the pages of a book online, on the publishing company website. The American book promotion specialist S. Miller lists websites of writers and communication of authors with bloggers among the ways of editions' promotion, but far from every Ukrainian writer has official website, and some of existing websites become outdated caused by the lack of fresh information. However, sometimes there is an access to some authors' works (for example, on websites of Oksana Zabuzhko, Vasyl Shkliar, Ivan Andrusiak, Mila Ivantsova). In this context the «Master Class of Andrii Kurkov» («Bukvoid») is should be noted, where the famous writer analyzes novellas and stories of little-known authors. Authors' blogs can be find more often. An interesting and worthy to follow is an experience of Borys Akunin, who issued his blog as the «Love to History» book. The Russian writer is actively works with the followers in the Internet. For example, in 2000, he offered readers to continue the «Table-talk of 1882» story, and he promotes the central figure of his historical detective series Erast Fandorin, creating the website of this character (http://fandorin.ru).

In the «Mirror Weekly. Ukraine» ${ }^{6}$ the publishers could express their opinions on the role of the Internet in formation of the book-reading culture. In particular, Olena Movchan, the lead editor of «Hrani-T»

5 Лукина М. М. СМИ в Интернете. Средства массовой информации России: учеб. пособ. для студентов вузов / М. И. Алексеева, Л. Д. Болотова, Е. Л. Вартанова и др.; под ред. Я. Н. Засурского. Москва: Аспект-Пресс, 2006. С. 355.

6 Фіалко Д. Невже іï врятує Інтернет? Дзеркало тижня. 2013. № 16. URL: http://gazeta.dt.ua/CULTURE/nevzhe-yiyi-vryatuye-internet-_.html (дата звернення: 22.06.2019). 
publishing company, noted: «Today the Internet is the only place to promote books and reading, where you can play by your rules, with own style and information selection, inviting readers to your own territory, i.e. a website and publisher's pages on social networks. Thanks to the Internet, it's plain to see the level of readers' activity. The number of users of our publishing pages and website is increasing - without sharp spikes, but gradually and steadily. Sales on the Internet are gradually increasing too. As well as we are working at the increasing a culture of the Internet use among children, holding competitions in the Internet. We offer to stop fight "the windmills" - the Internet which become an integrated reality of our time. Every child has a right and has to live in a modern world, be able to use it for own comfortable development» ${ }^{7}$.

Viktoriia Rudenok, the development manager of the «Chytaika» book project, noted, that the most active audience among their accounts is on the Facebook platform ${ }^{8}$.

Social networks open up unique opportunities of contact between authors and readers. Facebook allows to look through recommendations in the «Books» tab and share with friends own read editions; in the «Communities» tab you can find groups which are selling, advertising or promoting book products, publishing companies, authors, ect; Twitter is interesting by tweets of authors, literary critics, celebrities, who recommend to read certain works; in VKontakti thanks to the «My Communities» tab you can find pages of book shops, groups dedicated to certain authors or books, as well as groups of publishing companies, book shops or social book projects.

In Ukrainian Facebook Yurii Izdryk maintains his own «poetry feed» in almost daily format, and he confesses: «For me, Facebook is a tool. It's a platform through which I contact with readers. Directly. Every day. Without communication with a publisher, searching some compromises on what the book should be, royalties, presentation and so on. Personally

7 Фіалко Д. Невже їі врятує Інтернет? Дзеркало тижня. 2013. № 16. URL: http://gazeta.dt.ua/CULTURE/nevzhe-yiyi-vryatuye-internet-_html (дата звернення: 22.06.2019).

${ }^{8}$ Фіалко Д. Невже іï врятує Інтернет? Дзеркало тижня. 2013. № 16. URL: http://gazeta.dt.ua/CULTURE/nevzhe-yiyi-vryatuye-internet-_.html (дата звернення: 22.06.2019). 
me is not really excited at all with the opportunity to issue another one book, if there is a possibility of publishing on Facebook. ... At least, if it is about Facebook - I do not use VKontakti, there are completely different audience. That is I am not there, but my poetry is presented there too - there is a fan club, which is reposting my poetries, but I have nothing to do with it. I publish my texts on Facebook and, in parallel, on a habit - on LiveJournal» ${ }^{9}$.

To interest someone in reading is possible through book social networks (Bookmate, Bookmix, Goodreads, Imho.net, Librarything.org, LibraryThing, LiveLib.ru, Reader2, Readrate, Riffle Books, Shelfari, The Reading Room, Two-books, Wattpad, weRead, X-Libris, BookRiver, Books in hands, My Library (My-Lib.ru), etc). One of the most popular is Goodreads, where you can create own bookshelves, subscribe for news, comment friends' choices. As of 2014, S. Vodolazka records only two Ukrainian book social networks - Book.ua and Findbook.com.ua. To our opinion, this list can be extended, taking the above mentioned definition into account, with the network resources as the «Poetry Workshops» (maysterni.com/contest.php) and «Poetry and Author Songs of Ukraine» (poezia.org/ua). Moreover, speaking about the second one, according to information provided on the site, on the poezia.org domain name, in 2003 , the resource started the «Poetry and Author Songs of Vinnychchyna» project, and the updated version, which can be added to the book social networks, which started to work at the beginning of October, 2006. ${ }^{10}$ Also the Bookchalleng_ua project of writers Kateryna Babkina and Mark Livin should be mentioned too.

Today, through the Internet it is possible to access the resources of libraries of various levels. Ukrainian «Poetry Workshops» project allows authors to publish their works with open access and communicate with readers in comments. The «Bukvoid» portal in the «Electronic Library» rubric provides a number of literary works for free online usage as well. According to results of our survey for 9-11 grade pupils of Zaporizhzhia

\footnotetext{
${ }^{9}$ Паньо К. Юрій Іздрик: від «Четверга» до «щодня». Дзеркало тижня. 2015. № 50. URL: http://gazeta.dt.ua/CULTURE/yuriy-izdrik-vid-chetverga-do-schodnya-_html (дата звернення: 22.06.2019).

${ }^{10}$ Поезія та авторська книга України: сайт. URL: http://poezia.org/ (дата звернення: 22.06.2019).
} 
city, $42,33 \%$ of responders, answering a question from where they got books they have read, pointed the very Internet as a resource: «downloaded for free or read in the Internet».

Online television, for example, «Book.UA» («First National») program allows to learn more about a book. In recent years, a phenomenon such as a book trailer has been actively developing. Today, it is prestigious to have own channel of a publishing company on YouTube, where can be posted interviews with authors, videos from presentations, book trailers. Only few Ukrainian publishing companies have such channels: «Vydavnytstvo Annety Antonenko», «Vydavnytstvo Staroho Leva», «Hrani-T», «Klio», «Liliia», «Navchalna knyha Bohdan», «Osnovy», «Ranok», «Svitych», «Svichado», «Artkompleks», «Folio», «Meridian Czernowitz». It is rational to adopt practices of international bibliophiles, who share their impressions of books they have read, on YouTube.

In addition, computer games, based on literary works, can help to promote books.

In general, A. Sudyn offers to categorize all the online media in the field of information about books in such way (all of them one way or another aimed at formation of reading culture, therefore they are interesting within our research): websites of market structure (publishing companies, book networks and book shops), created for the purpose of advertising; websites of online bookshops (also of advertising content); websites of traditional book shops, which is trading through the Internet too; websites of literature and critical content; children's book websites, most related to libraring children's reading; libraries websites; websites of so called electronic libraries; websites recreating periodicals, which discussing the literature and books (literature and critical publishings); websites that speak about culture and art, and where may be (or are) pages about a book, or discussion of a reading; websites, which can be considered as specialized book online media ${ }^{11}$.

\footnotetext{
${ }^{11}$ Судин А. Книжкові інтернет-видання як наявна альтернатива відсутній друкованій фаховій періодиці. Книгобачення: український видавничий портал. URL: http://knyhobachennia.com/?article=665 \&category=2 (дата звернення: 22.06.2019).
} 
In view facts we have set before, this classification should be supplemented with online television, own channels of publishers and authors on YouTube.

\section{Formation of reading culture at the example of PocketBook}

Today, we are witnessing the third revolution in reading, related to spread of electronic publications, and, therefore, a change of reading culture and book consuming. Publishing market representatives are forced to look for new forms of communication with consumers. S. Vodolazka stresses, that the result of such search is innovative publisher's promotions (product placement, branding, book trailer, crowd funding), innovative channels of network communication (universal and specialized social networks, online projects, video hosting, blogs and micro blogs, forums, chats, social services $)^{12}$. In this context, the activities of PocketBook company are of particular interest.

In Ukraine, the devices of PocketBook trademark are presented in most part of IT-aggregators, online and offline shops and supermarkets of electronic. Today, among the official partners of PocketBook are: ALLO, COMFY, ELDORADO, Foxtrot, Moyo, Portativ, Technopolis, Mobilochka, Rozetka, Sokol. PocketBook company has $49 \%$ of E Inkdevices market in Ukraine in monetary terms and $38 \%$ in units sold ${ }^{13}$.

Reader is a device designed primarily for a comfort reading and capable of holding several thousands of books, which you can take along everywhere. Unlike most screen devices, this one does not cause discomfort or damage the sight, because E Ink-display is illuminated by reflected light like paper. The reader needs to be charged once a month, which is very convenient during vacations and business trips. The most important thing in the reader is the «Library» section. Developers have provided convenient ways to group and sort books. Through experiments, you can choose a convenient display mode.

12 Водолазька С. А. Інновації у видавничій галузі східноєвропейського регіону: прогностичні оцінки. Актуальні питання масової комунікації. 2013. Вип. 14. С. 79.

13 Pravdivaja istorija PocketBook. Forbes Україна. URL: http://forbes.ua/magazine/ forbes/1350311-pravdivaya-istoriya-pocketbook (дата звернення: 22.06.2019). 
The useful function of the «Library» is a search by a word or phrase of the needed book, if the user forgot the exact location of it on a flash card or onboard memory.

Advantages of the PocketBook reader are: support of a great number of electronic book formats (table 1); well-arranged navigation system (it's very convenient to turn the pages); E-Ink system; high speed of work; set of fonts for displaying of text format books; easy setup of library; integrated Lingvo dictionaries ${ }^{14}$.

Table 1

General requirements for electronic books in PocketBook readers ${ }^{15}$

\begin{tabular}{|l|l|l|}
\hline \multicolumn{1}{|c|}{ Criterion } & \multicolumn{1}{|c|}{ Characteristics } \\
\cline { 2 - 4 } Formats & OML-based & ePub, FictionBook, XHTML, XMDF \\
\hline \multirow{5}{*}{ Reading } & Software & $\begin{array}{l}\text { BBeB, CBR/CBZ, LIT, Mobipocket/Kindle, PDF, } \\
\text { Plain text }\end{array}$ \\
\hline \multirow{5}{*}{ Editing } & $\begin{array}{l}\text { Adobe Acrobat, Adobe Digital Editions, Aldiko, } \\
\text { Blio, Bluefire Reader, Bookglutton, Calibre, } \\
\text { FBReader, Foxit, Reader, iBooks, Lexcycle } \\
\text { Stanza, OverDrive Media Console, Sony Reader } \\
\text { Library, STDU Viewer, Sumatra PDF }\end{array}$ \\
\hline Sources & Free & $\begin{array}{l}\text { Adobe InDesign, Aquafadas, Atlantis Word } \\
\text { Processor, Calligra Author, Feedbooks, iBooks } \\
\text { Author, LaTeX, Sigil }\end{array}$ \\
\cline { 2 - 4 } & Paid & $\begin{array}{l}\text { Aozora Bunko, Baen Free Library, Bookglutton, } \\
\text { Feedbooks, Google Books, HathiTrust, Internet } \\
\text { Archive, Issuu, Project Gutenberg, Smashwords, } \\
\text { Wikibooks, Wikisource }\end{array}$ \\
\hline & $\begin{array}{l}\text { Amazon.com, Barnes \& Noble, BooksOnBoard, } \\
\text { Booktrack, Borders, Feedbooks, Fictionwise, } \\
\text { Google Books, iBookstore, Kobo Bookstore, } \\
\text { Smashwords, Sony Reader Store }\end{array}$ \\
\hline
\end{tabular}

But the mentioned advantages make no matter, if the society does not have fans of reading as a vital need, that's why the company pays a lot of attention not only to improving the technical characteristics of its devices, and a result of this is a number of awards and prizes (table 2),

14 Український клуб любителів електронних книг. URL: http://www.ebookua.org/content/oghliad-chitalki-pocketbook (дата звернення: 22.06.2019).

${ }^{15}$ PocketBook International. URL: http://uk.wikipedia.org/wiki/PocketBook International (дата звернення: 22.06.2019). 
but to formation of interest in reading books and reading in general, and it will be considered later.

As V. Teremko rightly points out, «the problem is not which information-carrying medium people use for reading, but for what purpose and how they read. The main thing is a culture of reading in the structure of personality» ${ }^{16}$. The activity of PocketBook company shows that its owners understand it, so let's consider its social and communication measures in details.

Table 2

Awards and prizes of PocketBook ${ }^{17,18}$

\begin{tabular}{|c|c|c|c|}
\hline Year & Nomination & Award/prize & Device \\
\hline 2012 & $\begin{array}{c}\text { ToпTop } 10 \text { sales of } \\
\text { Pixmania }\end{array}$ & Pixmania & $\begin{array}{l}\text { PocketBook Pro 912, } \\
\text { Basic 611, Touch }\end{array}$ \\
\hline 2012 & $\begin{array}{l}\text { The best reader in } \\
\text { Europe }\end{array}$ & Computer Bild & PocketBook Touch \\
\hline 2012 & The best design & $\begin{array}{c}\text { Red Dot } \\
\text { Design Award }\end{array}$ & PocketBook A10 \\
\hline 2012 & $\begin{array}{l}\text { The winner among } \\
\text { electronic readers with } \\
\text { multitouch displays }\end{array}$ & Tablet PC & PocketBook Touch \\
\hline 2012 & $\begin{array}{l}\text { The winner of electronic } \\
\text { readers rating }\end{array}$ & PC Format & $\begin{array}{c}\text { PocketBook Touch, } \\
\text { PocketBook Basic, } \\
\text { PocketBook Basic New }\end{array}$ \\
\hline 2012 & $\begin{array}{c}\text { Product of the year } 2012 \\
\text { («Mobile and digital } \\
\text { devices») }\end{array}$ & $\begin{array}{c}\text { Consumer } \\
\text { Electronics \& } \\
\text { Photo Expo } \\
\end{array}$ & PocketBook A 10" 3G \\
\hline 2012 & $\begin{array}{l}\text { Russia. The best of the } \\
\text { best } 2011(« \text { Electronic } \\
\text { books») }\end{array}$ & $\begin{array}{c}\mathrm{PC} \\
\text { Magazine/RE }\end{array}$ & PocketBook Pro 612 \\
\hline 2013 & The best $\mathrm{E}$ Ink reader & allesebook.de & PocketBook Touch Lux \\
\hline 2013 & The best E Ink reader & Tablet PC & PocketBook Touch Lux \\
\hline 2019 & $\begin{array}{l}\text { TV and home } \\
\text { entertainment, E-readers }\end{array}$ & $\begin{array}{c}\text { Red Dot } \\
\text { Award: } \\
\text { Product } \\
\text { Design } 2019\end{array}$ & $\begin{array}{l}\text { PocketBook Touch HD } 3 \text {, } \\
\text { PocketBook Touch Lux } 4\end{array}$ \\
\hline
\end{tabular}

16 Теремко В. Видавництво-ХХІ. Виклики і стратегії: монографія. Київ: Академвидав, 2012. C. 227.

${ }^{17}$ PocketBook International. URL: http://uk.wikipedia.org/wiki/PocketBook International (дата звернення: 22.06.2019)..

18 Рідери PocketBook отримали нагороду Red Dot Award за найкращий дизайн продукту. URL: https://telegraf.design/news/ridery-pocketbook-otrymaly-nagorodu-red-dotaward-za-najkrashhyj-dyzajn-produktu/ (дата звернення: 16.07.2019). 
The company presented three projects, aimed at the promotion of reading:

1. KidRead is a project which helps to manage the time a child spends with the mobile device. The unique software is created to engage children in reading, as well as to control and test the child's literary knowledge. The KidRead project consists of kidread.com website and Android application for multimedia readers and tablets.

2. ReadRate is a search and recommendation service, the main aim of which is help in the selection of literature. On the base of ReadRate online platform you can get information about the most popular books, get acquainted with book ratings, literary preferences, reviews and analysis of other users.

On the ReadRate website you can create the reader's personal page, discuss the book you like, or, conversely, don't like, save an interesting quotation or make a list of literature works you plan to read in the nearest future. When a user marks on the own page preferences in works and authors, over time the system will be able to offer books, matching the reader's interests. Actually, every owner of a PocketBook reader with the Internet access can be a «jury» member, which can give a life to certain book. The ReadRate project is linked to Facebook, LinkedIn, Twitter, VKontakti and Odnoklasnyky social networks it is possible to log in the website through the account in one of which popular social networks ${ }^{19}$.

3. BookLand is an electronic platform of PocketBook, the purpose of which is to sell fiction, educational, reference works, as well as periodicals in electronic format. BookLand offers more than 1,5 million of titles of electronic content in 17 languages.

PocketBook company is an active society figure and the main sponsor of competitions, and this is one of components of its contribution into the development of society culture. Let us list some of them, which had been held in Ukraine:

1. The «Best Reader in Ukraine» competition of children's reading, organized jointly with the «Publishers Forum» public organization, National Library of Ukraine for Children, Ukrainian Association of

\footnotetext{
${ }^{19}$ ReadRate - офіційний сайт. URL: http://readrate.com/rus/collections (дата звернення: 22.06.2019)
} 
Library Workers for Children, Ukrainian Library Association and Ukrainian Association of Publishers and Book Distributors ${ }^{20}$.

2. The PocketBook «Miracle Book» competition, on which the participants had to submit an own project of a book of the future, describing its look and the principle of its use ${ }^{21}$.

3. The «Coronation of Word» international literary competition of novels, plays, screenplays, song lyrics and works for children. In 2013, PocketBook company has traditionally become a partner of the award. Within the competition program the honorary jury of the competition studied the literary works of nominees, using PocketBook readers ${ }^{22}$.

4. The «Reading with Pleasure» with PocketBook competition ${ }^{23}$.

5. The literary critics competition, the organizer of which was «Bukvoid» book portal, and the main sponsor was PocketBook ${ }^{24}$.

6. The literary competition for all talented mothers, who feel able to and have a will to write a book or a story for children, organized by Glowberry Books publishing company and PocketBook International company $^{25}$.

7. The «Children in travel: the most funny stories» competition, organized by National Geographic in joint with PocketBook ${ }^{26}$.

The company organizes competitions for people of various talents: writer, critic, artist, inventor, and, of course, reader. PocketBook take part in international competitions, as well as in all-Ukrainian, and of less scale, for example, within a city. For instance, on March 6, 2015, the company initiated a flashmob to promote reading in Kyiv, by asking on its pages in social networks to come with own reader to the «Polytechnic Institute»

20 Конкурс дитячого читання «Найкращий читач України». URL: http://laginlib.org.ua/images/news/1.pdf (дата звернення: 22.06.2019).

${ }_{21}$ Конкурс «Чарівна книга від PocketBook. URL: http://4pda.ru/forum/index.php?showtopic=591466 (дата звернення: 22.06.2019).

22 Літературний конкурс «Коронація слова» за підтримки PocketBook. URL: http://www.pocketbook-int.com/ua/uk/news/pocketbook_koronaciya_slova (дата звернення: 22.06.2019).

23 Конкурс «Читання в задоволення» 3 PocketBook. URL: http://www.svyaznoy.ru/news/?ID=1932290 (дата звернення: 22.06.2019).

24 Конкурс літературних критиків. URL: http://news.meta.ua/archive/ 23.05.10/cluster:16900956-Bukvojid-nazvav-peremozhtsia-ta-diplomantiv-konkursu-

literaturnikh-kritikiv (дата звернення: 22.06.2019).

25 Glowberry Books оголосило літературний конкурс для мам. URL: http://vsiknygy.net.ua/news/17325 (дата звернення: 22.06.2019).

${ }^{26}$ Конкурс «Діти в подорожі: найкумедніші історії». URL: http://zaprizami.ru/?p=2390. 
underground station entrance and join the book movement on escalator. Those who brought PocketBook readers, was encouraged with gifts.

PocketBook company presented in various social networks: Facebook, Twitter, YouTube, RSS, VKontakti, etc. With the help of them it holds own competitions of various directions, but most part of them is devoted the very reading of electronic books. The feature of social networks is that they bring people together by their interests, that allows to maintain dialogue and get a feedback, to react on needs and requests. V. Teremko stresses, that «online promotion essentially enrich, strength advertising activity... influents positively the book sales» ${ }^{27}$.

Appeal to celebrities. Many people trust authoritative, important for them individuals. There are a lot of proofs, that the audience reacts almost immediately to recommendations of people they respect ${ }^{28}$. Famous actors are role models, so the «Actors at reading» set of photos, offered on November 18, 2014, in social networks on PocketBook pages, serves the aim to promote book reading, too.

Some messages are accompanied by the image of PocketBook reader screen with the quotation of famous person (usually, a writer), for example:

«Striking words of writer Thomas Worton. So, when do you go there? "Even an hour of reading is a time spent in paradise"

«Fantasy author Neil Gaiman knows exactly, how to put own ideas in practice. "Books are dreams you can touch" «;

«Edmund Wilson, well-known critic and close friend of Fitzgerald, hit the nail right on the head! "There are no two identical readings of one book" «;

«Perhaps, nobody can say better than Alice Hoffman. After all, children's writers know something about life: "Books are the only one magic exists" «;

«Jackson Holbrook has found a way to discover the whole truth about any person the world over. "Your library is your portrait" «.

As O. Ovrutskyi notes, "visual elements of image fulfill specific functions of emotion influence. Verbal elements fulfill informative function, motivating function, as well as system-creating one (positioning). Identifying function is universal for verbal and visual

\footnotetext{
${ }^{27}$ Теремко В. І. Видавничий маркетинг: навч. посіб. Київ: Академвидав, 2009. С. 229.

${ }^{28}$ Прингл Х. Звезды в рекламе. Москва: Эксмо, 2007. С. 382-383.
} 
elements of advertise image» ${ }^{29}$. In the above mentioned examples there were used both visual (PocketBook reader display) and verbal (quotation) elements.

The organizers post on their pages interesting phrases, motivating the group participants to read and respect books, for example:

«There are books which can be recognized just by a few words»;

«There is nothing more beautiful than books in a book shop. It's magic of written words»;

«When you hear your kid reading on its own, you wonder, how the kid has grown up this quickly. Right?»;

«With a book even at the very edge of the world you will never be alone»;

«The most treasured thing in reading is not an epilogue, but pleasure with the story flow»;

«An interesting book is a kind of magic wand, that can make any furniture the most comfortable in the world»;

«Don't be surprised when reading will cause an unusual physical feelings - it's your wings are growing»;

«The one who reads, can live thousands of lives together with book characters. And in this is a great happiness of reading»;

«A person with the same kind of reader as yours, generates sympathy. And when you see on the screen a favorite book, you understand that met a friend for a life!»;

«It's possible to travel in space and time! It can prove anybody, who likes reading!»;

«Book yoga is the special poses for reading, which help to hide from unnecessary worries».

All texts are accompanied by appropriate images. Although the company is primarily interested in the electronic books promotion, we can see kind words, addressed to a bookshop. Doctors will hardly approve the «book yoga», but it was stressed that you can read in any comfortable pose. All the abovementioned quotations are aimed at the formation of book perception as a constant companion of life, which makes it richer and brighter.

29 Овруцкий А. В. Соотношение визуального и вербального в рекламном образе. Визуальные коммуникации и реклама в дизайне / под ред. В. О. Пигулевского. Харьков: Гуманитарный центр, 2011. С. 180. 
A number of posts recommend leisure activities, related to book plot:

«A desire to be unstandrard distinguishes the bibliophiles among others. For example, five in ten people will be dressed up as Dracula, ghost or witch on Halloween. But you can stand out of others, becoming for the evening a character of one of the contemporary horror stories. ReadRate has made a list for you»;

«Designer and writer Diana Fried cooks dishes, featuring in classic literature, for example, in "The Kill of Mockingbird" by Harper Lee or "The Great Gatsby" by Fitzgerald. And did you immediately guessed, which works are in photo?»;

"The "Bulhakovskyi" book club was opened in the basement of Mykhail Bulhakov museum on Andriivskyi Descent» (https://www.facebook.com/bulgakov.book.club). This is a perfect place for a bibliophile: here you can retire into yourself and read or discuss the last book news over a cup of tea. Also, there are weekly film presentations, lections, literature readings and chamber music events»;

«The Junibacken Fairytale Museum in Stockholm. This is such a cool place, that will be interesting both for children and adults. The museum features places modeled from various children's works of Sweden writers, and you can play there, not only see them. And the main bonus is a fairytale train, on which the visitors travel through scenes from Astrid Lindgren books»».

Many of content on social networks pages, provides tips on how to get acquainted with works of winners of prestigious literary awards and other prizes or encourages users by posts, dedicated to specific events, to read a certain book or author:

«Dave Egger's new novel, the "Sphere", is a must-read book of this week. The author skillfully describe the hidden reefs of new media and consequences of being honest in the Internet. Read and remember, if you want be ready for tomorrow!»;

«This week, PocketBook advice to read the biography of the great Charlie Chaplin, written by the brilliant Piter Ackroyd, in which he told in details about the shooting of the "Gold Rush" and relationships of the maestro with his second wife Lita. The book, which will be liked both literature-passionate people and film devotees»;

«Meet the best Ukrainian book of 2014 according to BBC Book of the Year, the "Felix Austria" novel by talented Sofiia Andrukhovych. 
Inside, there is an incredible story of two women in the scenery of Stanislavov-Frankivsk of the beginning of XX century»;

"The "Blacker than Black" is a novel of one of the most interesting authors of England, Booker Prize winner, Hilary Mantel. The dramatic, absorbing story about the other side of modern spiritual world of England, where the main characters are a visionist who sees spirits all the time and her assistant... Must-read for all admirers of mystic realism!»;

«For sunny weather we choose the same books - the "Flavor of Fresh Raspberry" by the Polish writer Isabella Sova. Full of humor, the romantic story about the search of women happiness - this is what we need in the beginning of spring!»;

«In memory of Terry Pratchett let's reread his brilliant "Flat World". Whatever novel or story of the series you choose, the fantasy of the highest quality, spiced with English humor, is waiting for you»;

«Today, poet Lina Kostenko celebrates her anniversary - 85 years! Thank you, Lina Vasylivna, for inspiring us by every word!»;

«This week we bring to mind the writing debut of Andrii Kuzmenko "Me, "Pobieda" and Berlin". In there, Kuzma published not only texts of the best Skriabin's songs, but two novelettes, written in recognizable style of Andrii - humorous and extremely cheerful».

Therefore, the interests of Ukrainian readers were taken into account, because the figure of Lina Kostenko is significant for national literature. The death of famous singer Andrii Kuzmenko shocked everyone, so the mention about him on the PocketBook pages (both reader's and in social networks) is relevant.

There are also references to articles, which show how the reader makes life easier:

"Colleagues from gagadget.com have conducted the test drive of the flagship Sense reader with a stylish Kenzo cover. You can read about the features of adaptive highlightning and ease of operation of Dropbox by the link: http://bit.ly/1z23141»;

«Wonderful Anna Sarapion, the author of Capsule blog, took for vacation PocketBook Ultra instead of very heavy books. What has become of it, you can learn from the blog: http://bit.ly/1wAuNQV. Spoiler: it turned out, that Ultra is an irreplaceable thing in travels. Thank you for response!»; 
«We sent InkPad in classes: RootNation tested, how the reader makes student's life easier. What has become of it, you can learn by the link: http://bit.ly/1z2id2H».

As we can see, on the pages in social networks PocketBook conducts soft sell of its readers, recommending information about the products, and at the same time forming the reading culture of target audience.

\section{CONCLUSIONS}

Compared to other European countries, Ukraine has a limited number of purely book-oriented online sources. This has a negative impact on the formation of national public opinion, because books are the source and tool of training of educated competitive nation. However, there are positive developments in the Internet promotion and spreading with its help a range of possibilities of formation of reading culture. For example, every year the more and more people are covered with free, open, objective and unbiased information about books, and due to this later on they will be able to navigate in modern information space, to create new forms of interaction.

There are publishing companies, which did not spare money and time to create own web-pages, and, no doubt, they has improved their status by it, for example, «A-ba-ba-ha-la-ma-ha», «Vydavnytstvo Staroho Leva», «Folio», etc. Today, social networks of general topics are the most popular among of their kind. In Ukraine it's Facebook and Twitter. There are special book-oriented social networks to simplify the search of interesting books and organize the own library; there you can find likeminded people and share your impressions from the reads: Goodreads, Rubuki, Wattpad, Readrate, Riffle Books, Shelfari, Librarything, LiveLib.

Today, it's prestigious to have own channel of a publishing company on YouTube, where can be posted interviews with authors, videos from presentations, book trailers. Only few Ukrainian publishing companies have such channels: «Liliia», «Ranok», «Svitych», «Osnovy», «Vydavnytstvo Annety Antonenko», «Svichado», «Meridian Czernowitz», Artkompleks», «Klio», «Folio», «Vydavnytstvo Staroho Leva», «Navchalna knyha - Bohdan», «Hrani-T».

The united team of PocketBook specialists provides high quality and exclusivity of products to satisfy all possible needs of modern readers. For today, the PocketBook company presented in the world market more 
than 50 models of electronic E Ink-readers and multi-media tablets, most part of which became novations in the sphere of electronic reading and won prestigious international awards. These readers have a simple interface and support almost all popular text formats. The PocketBook company is not only the e-book manufacturer, but an active society figure. Holding the leading positions on the market, it is one of the most influential subjects of formation of reading culture. This is proved by: its projects, such as KidRead, ReadRate, BookLand, and numerous competitions and festivals, in which the company is a sponsor or initiator; by prestigious awards and prizes won by the company; by its intense activity in social networks; by creation of own projects on book promotion among the moder generation of the Internet consumers.

In 2019, the company plans both to update the readers range, and to deep the integration of all services in unified software solution, which is Android and iPhone application, integration with the ReadRate.com service and Bookland.ru shop; to launch on market the brand new PocketBook CAD Reader Flex device with a flexible 13,3-inch E Ink Mobius display - this is a professional device for reading drawings, schemes and voluminous technical documentations, which is able to replace by itself a stack of various papers, that specialists have to bring along at a remote object.

The pages of social networks are constantly spreading very topical, unique information (in particular, about the measures initiated by the company) and encourage feedback. The PocketBook conducts soft sell of its readers, recommending information about the products, and at the same time forming the reading culture of target audience through the appeal to celebrities, by image of PocketBook reader screen with the quotation of a famous person (usually a writer) or interesting phrases, motivating the group members to reading and respectful attitude to books, as well as recommending ways of leisure activities, related to a book plot, providing tips on getting to know the works of winners of prestigious literature prizes and awards, publishing posts devoted to certain events, and links in articles, which show how a reader makes life easier.

\section{SUMMARY}

The article deals with the social and communication events of PocketBook company, which introduced to the world market more than 
30 models of electronic E Ink readers and multimedia tablets, most part of which became innovations in the electronic reading sphere. It was found that PocketBook company is not only the manufacturer of e-book, but the active public figure, one of the most affluent subjects of the readers' culture formation. It's confirmed by its projects as KidRead, ReadRate and BookLand, as well as numerous competitions and festivals, in which the company is acting as an initiator or sponsor (The Best Reader of Ukraine, Magic book, Reading for Pleasure, Children in a Journey: the Most Funny Stories etc.); prestige prizes and awards, gained by the company, its vigorous activity in the social media.

\section{REFERENSES}

1. Водолазька С. А. Інновації у видавничій галузі східноєвропейського регіону: прогностичні оцінки. Актуальні питання масової комунікації. 2013. Вип. 14. С. 76-80.

2. Кількість інтернет-користувачів в Україні продовжує зростати. РБК-Украӥна: сайт. URL: https://www.rbc.ua/ukr/news/ kolichestvo-internet-polzovateley-ukraine-1558443228.html (дата звернення: 22.06.2019).

3. Кількість регулярних інтернет-користувачів в Україні зросла до 21,8 млн. gazeta.ua. URL: http://gazeta.ua/articles/life/_kilkistregulyarnih-internetkoristuvachiv-v-ukrayini-zrosla-do-218-mln/633061 (дата звернення: 22.06.2019).

4. Конкурс «Діти в подорожі: найкумедніші історії». URL: http://zaprizami.ru/?p=2390 (дата звернення: 22.06.2019).

5. Конкурс «Чарівна книга» від PocketBook. URL: http://4pda.ru/forum/index.php? showtopic=591466 (дата звернення: 22.06.2019).

6. Конкурс «Читання в задоволення» 3 PocketBook. URL: http://www.svyaznoy.ru/news/?ID=1932290 (дата звернення: 22.06.2019).

7. Конкурс дитячого читання «Найкращий читач України». URL: http://laginlib.org.ua/images/news/1.pdf (дата звернення: 22.06.2019).

8. Конкурс літературних критиків. URL: http://news.meta.ua/ archive/23.05.10/cluster:16900956-Bukvojid-nazvav-peremozhtsia-tadiplomantiv-konkursu-literaturnikh-kritikiv (дата звернення: 22.06.2019). 
9. Літературний конкурс «Коронація слова» за підтримки PocketBook. URL: http://www.pocketbook-int.com/ua/uk/news/ pocketbook_koronaciya_slova (дата звернення: 22.06.2019).

10. Лукина М. М. СМИ в Интернете. Средства массовой информации России: учеб. пособ. для студентов вузов / М. И. Алексеева, Л. Д. Болотова, Е. Л. Вартанова и др.; под ред. Я. Н. Засурского. Москва: Аспект-Пресс, 2006. С. 338-355.

11. Овруцкий А. В. Соотношение визуального и вербального в рекламном образе. Визуальньле коммуникации и реклама в дизайне / под ред. В. О. Пигулевского. Харьков: Гуманитарный центр, 2011. С. 170-194.

12. Паньо К. Юрій Іздрик: від «Четверга» до «щодня». Дзеркало тижня. 2015. № 50. URL: http://gazeta.dt.ua/CULTURE/yuriy-izdrikvid-chetverga-do-schodnya-_.html (дата звернення: 22.06.2019).

13. Поезія та авторська книга України”. URL: http://poezia.org/ (дата звернення: 22.06.2019)

14. Прингл Х. Звезды в рекламе. Москва: Эксмо, 2007. 432 с.

15. Рідери PocketBook отримали нагороду Red Dot Award за найкращий дизайн продукту. URL: https://telegraf.design/news/riderypocketbook-otrymaly-nagorodu-red-dot-award-za-najkrashhyj-dyzajnproduktu/ (дата звернення: 16.07.2019).

16. Судин А. Книжкові інтернет-видання як наявна альтернатива відсутній друкованій фаховій періодиці. Книгобачення: український видавничий портал. URL: http://knyhobachennia.com/?article=665\& category= 2 (дата звернення: 22.06.2019).

17. Тенденции мирового рынка ридеров от PocketBook. URL: http://lit-ra.info/news/Tendentsii-mirovogo-rynka-riderov-otPocketBook/ (дата обращения: 03.04.2019).

18. Теремко В. Видавництво-XXI. Виклики i стратегії: монографія. Київ: Академвидав, 2012. 328 с.

19. Теремко В. І. Видавничий маркетинг: навч. посіб. Київ: Академвидав, 2009. 272 с.

20. У 2015 році регулярно Інтернетом користувалося понад 58\% жителів України. URL: http://www.unian.ua/society/1254409-u-2015rotsi-kilkist-internet-koristuvachiv-v-ukrajini-stanovilo-ponad-58.html (дата звернення: 22.06.2019). 
21.Український клуб любителів електронних книг. URL: http://www.ebook-ua.org/content/oghliad-chitalki-pocketbook (дата звернення: 22.06.2019).

22. Фіалко Д. Невже іiї врятує Інтернет? Дзеркало тижня. 2013. № 16. URL: http://gazeta.dt.ua/CULTURE/nevzhe-yiyi-vryatuyeinternet-_.html (дата звернення: 22.06.2019).

23. Glowberry Books оголосило літературний конкурс для мам. URL: http://vsiknygy.net.ua/news/17325 (дата звернення: 22.06.2019).

24.PocketBook International. URL: http://uk.wikipedia.org/wiki/ PocketBookInternational (дата звернення: 22.06.2019).

25.Pravdivaja istorija PocketBook. Forbes Україна. URL: http://forbes.ua/magazine/forbes/1350311-pravdivaya-istoriyapocketbook (дата звернення: 22.06.2019).

26.ReadRate - офіційний сайт. URL: http://readrate.com/rus/ collections (дата звернення: 22.06.2019).

\section{Information about the author:} Bessarab A. O.,

Doctor of Science in Social Communications, Associate Professor, Professor at the Special Pedagogy and Special Psychology Department, Municipal Institution of Higher Education «Khortytsia National Educational Rehabilitation Academy» 59, Science town str., Zaporizhia, 69017, Ukraine; Professor of Journalism and Ukrainian Philology Department, Classical Private University 70b, Zhukovskoho str., Zaporizhia, 69002, Ukraine 